\title{
A Path Analysis of the Interrelationship Among EFL Learners' Humor Style, Anxiety, and Language Proficiency
}

\author{
Mohammad Zeinali \\ Farhangian University, Birjand, Iran \\ Morteza Amirsheibani \\ Office of Education, Tabas, Iran
}

\begin{abstract}
Humor is a complicated part of the human experience and therefore an important dimension of humanity's unique ability for language. The main purpose of this study is to find which dimension of humor styles can better predict anxiety and language achievement. The participants of the present study were 210 (103 female and 107 male) Iranian advanced EFL learners with different ages, both genders, and various educational backgrounds. Convenience sampling was employed to collect data. This study utilized one test and two questionnaires which are Preliminary English Test (PET), the Humor Styles Questionnaire (HSQ), and The Foreign Language Classroom Anxiety Scale (FLCAS). Path Analysis and Pearson correlation were used to analyze data. Results showed that all four sub-constructs of humor styles, affiliative humor $(\beta=-0.27, p<0.05)$, self-enhancing humor $(\beta=-0.31, p<$ $0.05)$, aggressive humor $(\beta=0.17, p<0.05)$, and self-defeating humor $(\beta=0.20, p<0.05)$ are significant predictors of learners' anxiety. However, among four sub-constructs of humor styles, only affiliative humor $(\beta=$ $-0.32, p<0.05)$, and self-enhancing humor $(\beta=-0.25, p<0.05)$ are positive significant predictors of learners' Language Achievement. In addition, language achievement is predicted negatively by anxiety $(\beta=-0.26, p<0.05)$. Two paths from aggressive humor to language proficiency $(\beta=0.09, \mathrm{p}>0.05)$, and from self-defeating humor to language proficiency $(\beta=0.07, p>0.05)$ were not significant and removed from the model. With regards to the field of foreign language, humor has been identified as a powerful means to decrease students' anxiety in a foreign language learning situations and it helps language learners in performing in a foreign language.
\end{abstract}

Keywords: humor, humor style, foreign language classroom anxiety

\section{Introduction}

Humor is a complicated part of the human experience and therefore an important dimension of humanity's unique ability for language. In fact, it views as one of the few universals applicable to all peoples and all languages all over the world (Askildson, 2005).

Many scholars have generally specified some causes for applying humor in classroom setting: its influence as a relaxing, comforting, and pressure reducing method, its humanizing influence on teacher image, and its influence of upholding/enhancing student attentiveness and enjoyment. In original language methodologies generating a constructive, safe and tension free environment in the class is a need for language learning 
procedure to take place. Humor, by reducing anxiety and pressure, can lead to class harmony among the language students and create learning procedure more effective and fun. $\mathrm{Cr}$. Ronald Berk says that the psychological and physiological profits of laughter can have a direct influence on teaching and learning, particularly in five important fields: teacher-learner rapport, classroom environment, student reaction, test performance, and student attendance (as cited in Azizinezhad \& Hashemi, 2011). Humor and laughter may not openly cause learning; nevertheless, humor makes an atmosphere that encourages learning. Indication documents that suitable humor, and humor that communicates to course components, attracts and sustains consideration, and processes a further comfortable and creative learning atmosphere (Banas, Dunbar, Rodriguez, \& Liu, 2011). Humor also decreases anxiety, improves involvement, and enhances motivation (Teslow, 1995).

However, although such extensiveness and scope, the influence of humor style on anxiety and attainment is hardly argued among language investigators or educators - perhaps even hardly applied in the classroom on a conscious level, the present research emphasizes on four scopes of humor style, two adaptive and two maladaptive, namely affiliative, self-enhancing, aggressive, and self-defeating proposed by Martin, Puhlik-Doris, Larsen, Gray, and Weir (2003).

Affiliative humor as one of adaptive styles is hypothesized to foster interpersonal associations in a non-hostile way (Martin et al., 2003). Persons applying this style will frequently crack jokes or create light of stressful circumstances to ease the pressure of others. These persons may create fun of themselves, while upholding their constructive self-image, with the objective of creation other feel better. Self-enhancing humor assists the self while simultaneously being accepting and non-injurious to others. People whose humor style is mainly self-enhancing will usually find laughter in the oddities of life and have a general funny opinion on the world (Martin et al., 2003).

Two other styles which are maladaptive are violent and self-defeating styles. Aggressive humor efforts to encourage the self-concept with little or no concern for the well-being of others. This kind of adverse humor is cooperative to the self only by ridiculing, extreme teasing, demeaning, or mocking others in effort to create oneself feel better. Self-defeating humor encompasses putting oneself down to attain the constructive appraisal of others. Usually, an individual applying this style of humor will let themselves to be the self-denigrating punch-line to a joke in hopes of amusing those around them (Martin et al., 2003).

The other core variable of the current research is foreign-language anxiety. It is characterized as a complex and multidimensional phenomenon (Young, 1991) that refers to "the feeling of tension and apprehension specifically associated with second language contexts, including speaking, listening, and learning" (MacIntyre \& Gardner, 1994, p. 284).

\section{Review of Literature}

A plethora of researches on the association between language learning and anxiety (Aida, 1994; Brown, 2000; Cheng, 2002; Ewald, 2007; E. K. Horwitz, M. Horwitz, \& Cope, 1986; Young, 1992). Saito and Samimy (1996) stated that anxiety has an important influence on language learning and success. Some researchers conclude that high levels of anxiety frequently have a negative result on the language acquisition procedure (Gregersen, 2003; Krashen, 1985; MacIntyre \& Gardner, 1991).

"Humor" has attracted the consideration of scholars regarding with SLA. Recently, there have been some efforts to empirically reveal the topic of L2 humor and the function of humor in language learning. Applying 
surveys, scholars have established that in some foreign-language classrooms, both teachers and students consider that humor serves constructive roles, like motivating learners (Ketabi \& Simin, 2009; Ziyaeemehr, Kumar, \& Abdullah, 2011). Others have required to understand L2 humor and its association to learning through examination of native-speaker (NS) and non-native-speaker (NNS) communication. According to the results of a case study including three advanced L2 speakers, Bell (2005) has discussed that humorous language play may outcome in deeper processing of lexical items, rendering them more memorable.

Some of the researchers also concentrated on the impact of humor on stress. Martin and Dobbin (1988) illustrated how a sense of humor can moderate the immunosuppressive effects of stress. In their research, samples of subjects' saliva were taken to check for secretory immunoglobulin A (S-IgA). S-IgA is part of the immune system's prevention against viral and bacterial infections. Their research indicated how humor, in significant levels, could be prevention against viral and bacterial infections. McClelland and Cheriff (1997) stated similar outcomes that recommend a good sense of humor is connected to a decrease in frequency and severity of colds.

Thorson, Powell, Sarmany-Schuller, and Hampes (1997) recognized humor as an instrument to cope with critical life difficulties. Research looked to determine that some individuals are further successful in adapting to serious losses later in life than others. Their research highlighted that those people also look to uphold an air of serenity. Study was clear that a sense of humor is connected with a constructive adaptation with age. This work had led Thorson and Powell (1993) to improve the Multidimensional Sense of Humor Scale (MSHS), a more valid tool of measurement in assessing dissimilar aspects of humor.

Another research seems to support the notion that humor can help one to cope with life stressors. Martin, Kuiper, Olinger, and Dance (1993) discovered that humor does more than prevent probable viral and bacterial infections. Humor also enhances an individual's self-concept and level of self-esteem. A person with humor is observed as having confidence. This research goes on to say that when people feel good about themselves, they also feel good mentally. In other words, overall psychological well-being is developed.

Nevertheless, Jordan (2002) discovered dissimilar consequences. He investigated the communication of humor and stress among the Asian learners. Intensive language learners completed self-report questionnaires measuring stress and humor. The Spearman association exposed that humor has no considerable influence on stress experienced by the Asian learners. When the level of humor was high, stress symptoms were high.

The above-cited literature represents a representation of available research regarding the association among humor, anxiety, and language learning. Although many researches illustrate how humor affects anxiety and learning, no study has been done on the interrelationship among EFL learners' humor style, anxiety, and language achievement in a single model. The main purpose of this study is to find which dimension of humor styles can better predict anxiety and language achievement. Figure 1 shows the hypothesized model of interrelationship among EFL learners' language proficiency, humor styles, and anxiety. To investigate the problem stated above, the researchers formulated the following research question:

Research Question: Is there any significant interrelationship among EFL learners' language proficiency, humor styles, and anxiety? 


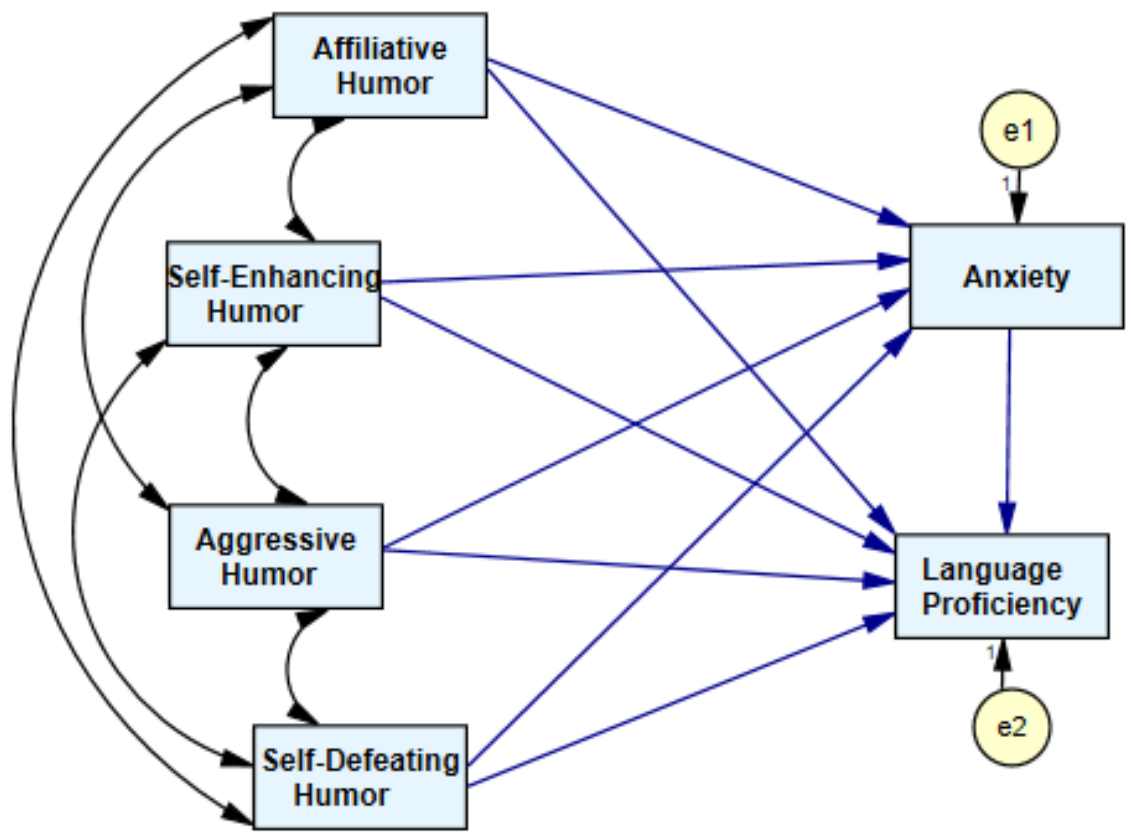

Figure 1. The hypothesized model of interrelationship among EFL learners' language proficiency, humor styles, and anxiety.

\section{Methodology}

\section{Participants}

The participants of the present study were 210 Iranian advanced EFL learners with different ages, both genders, and various educational backgrounds. They were 103 females and 107 males whose age varied from 19 to $37(M=25.67, S D=7.11)$. Convenience sampling was employed to collect data.

\section{Instruments}

The current study utilized one test and two questionnaires which are Preliminary English Test (PET), the Humor Styles Questionnaire (HSQ), and The Foreign Language Classroom Anxiety Scale (FLCAS).

Preliminary English Test (PET). In order to assess learners' level of proficiency, a sample of PET proficiency test (Cambridge ESOL Examinations, 2003) was utilized. This test has been composed of three parts: listening, reading, and writing. It is important to note that just one skill of the PET exam, i.e., reading skill, was used which was relevant to the purpose of the study. The reading section of this test includes 35 multiple-choice items providing simple written information, such as signs, brochures, newspapers, and magazines. Reliability of this test was calculated with Kuder-Richardson Formula 20 (KR-20) analyses and turned to be 0.85 for total reading test. It should be mentioned that PET is a standard test and its validity have been tested extensively.

Humor Styles Questionnaire (HSQ). Humor Styles Questionnaire is designed and validated by Martin et al. (2003). The scale consists of 32 items measuring four humour styles: affiliative humor, self-enhancing humor, aggressive humor, and self-defeating humor. Sample items are "I do not have to work very hard at making other people laugh-I seem to be a naturally humorous person" (affiliative), "If I am feeling depressed, I can usually cheer myself up with humor" (self-enhancing), "If someone makes a mistake, I will often tease 
them about it" (aggressive), and "I will often get carried away in putting myself down if it makes my family or friends laugh" (self-defeating). The instrument employs a 5-point Likert scale from 1 = "Totally disagree" to 5 $=$ "Totally agree". Internal consistencies (Cronbach's alpha) for sub-constructs of the scale ranged from 0.80 to 0.85 in this study.

The Foreign Language Classroom Anxiety Scale (FLCAS). The third instrument used in this study is the Foreign Language Classroom Anxiety Scale (FLCAS) developed by Horwitz et al. (1986). The FLCAS includes 33 items using a 5-point Likert scale, which ranges from "Strongly Agree" to "Strongly disagree". It measures students' self-reports regarding anxiety by adding up the ratings on the 33 items. The FLCAS's construct comprises three dimensions: (1) fear of negative evaluation; (2) communication apprehension; and (3) test anxiety. The focus of the present study is upon overall anxiety.

\section{Data Collection Procedure}

The data collection of this study took place in February and March, 2018. The present study was done among advanced English learners. This correlational study collected quantitative data through two questionnaires and one test: Preliminary English Test (PET), the Humor Styles Questionnaire (HSQ), and The Foreign Language Classroom Anxiety Scale (FLCAS). Respondents had two choices: They could receive either a paper-based survey or an online survey. The process took about one hour. Statistical Package for Social Sciences (SPSS 24) was used for data analysis and computing descriptive statistics, reliability analysis of the instruments, and Pearson Correlation Coefficient. Analysis of Moment Structures (AMOS 24.0) software was used to perform Path Analysis.

\section{Results}

To check the normality of data distribution, the Kolmogorov-Smirnov Test was employed. The results of the Kolmogorov-Smirnov Test indicated that the data are normally distributed across all three variables and parametric statistics can be utilized. Table 1 displays descriptive statistics of sub-constructs of humor styles, anxiety, and achievement including the number of participants, the mean, and the standard deviation.

Table 1

Descriptive Statistics of the Variables

\begin{tabular}{llll}
\hline & $N$ & Mean & Std. Deviation \\
\hline Affiliative humor & 210 & 28.00 & 6.11 \\
Self-enhancing humor & 210 & 26.96 & 4.24 \\
Aggressive humor & 210 & 20.16 & 3.89 \\
Self-defeating humor & 210 & 12.87 & 2.75 \\
Anxiety & 210 & 103.95 & 8.45 \\
Proficiency & 210 & 30.89 & 2.87 \\
\hline
\end{tabular}

As Table 1 shows, 210 learners participated in the present study. Besides it was found that among four humor styles, affiliative humor style (28.00) has the highest mean score and self-defeating humor style (12.87) has the lowest mean score.

Table 2 summarizes the information obtained from Cronbach's alpha analyses. As can be seen, the utilized scales gained acceptable indices of Cronbach's alpha. 
Table 2

Results of Cronbach's Alpha

\begin{tabular}{lll}
\hline Scale & Subscales & Cronbach's alpha \\
\hline \multirow{3}{*}{ Humor style } & Affiliative humor & 0.85 \\
& Self-enhancing humor & 0.81 \\
Anxiety & Aggressive humor & 0.80 \\
& Self-defeating humor & 0.85 \\
\hline
\end{tabular}

The alpha coefficient for total anxiety with 33 items is 0.86 , and for sub-constructs of the humor style scale range from 0.80 to 0.85 in this study which suggest that the items have relatively good internal consistency.

To answer the research question, Path Analysis was utilized. Figure 2 shows the schematic representation of the interrelationships among EFL learners' humor style, anxiety, and language achievement. To check the strengths of the causal relationships among the components, the standardized estimates were examined.

To check the model fit, goodness of fit indices were used. Because some measurement models did not show adequacy to the data, the researcher made some modifications on the model. These modifications included the removal of two non-significant paths (aggressive humor to language proficiency and self-defeating humor to language proficiency). Goodness of fit indices after modification can be seen in Table 3. In this study, $\chi^{2} / d f$, GFI, CFI, NFI, and RMSEA were used. To have a fit model, $\chi^{2} / d f$ should be less than 3 , GFI, CFI, and NFI should be above 0.90 , and RMSEA should be less than 008 . The model with all factor loadings can be seen in Figure 2.

Table 3

Goodness of Fit Indices

\begin{tabular}{llllll}
\hline & $\chi^{2} / d f$ & GFI & CFI & NFI & RMSEA \\
\hline Acceptable fit & $<3$ & $>0.90$ & $>0.90$ & $>0.90$ & $<0.08$ \\
Revised model & 2.94 & 0.911 & 0.940 & 0.931 & 0.078 \\
\hline
\end{tabular}

As Table 3 shows, all the goodness of fit indices are within the acceptable range. Therefore, the scale enjoyed a perfect validity. 


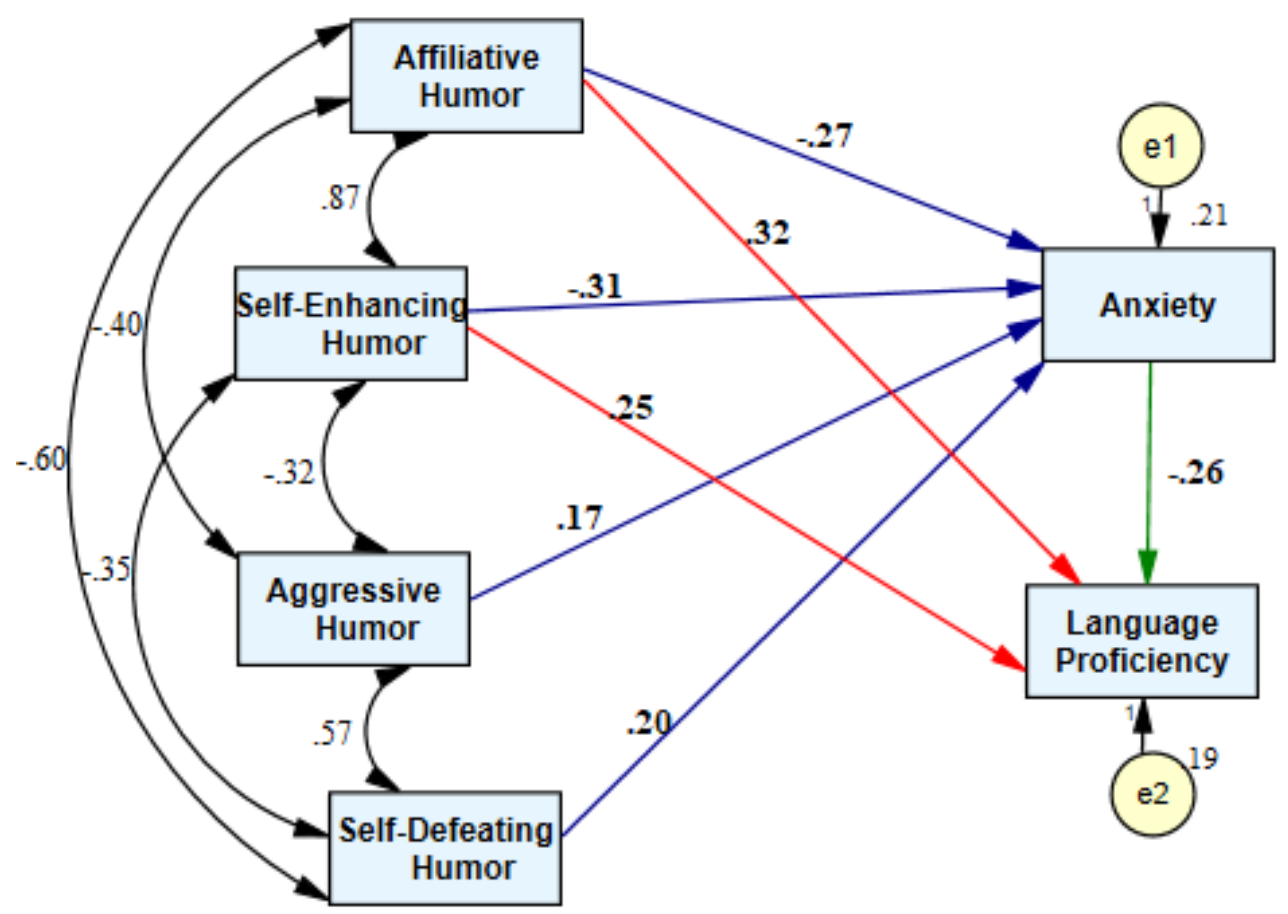

Figure 2. The schematic representation of the interrelationships among EFL learners' humor style, anxiety, and language achievement

As indicated in Figure 2, all four sub-constructs of humor styles, affiliative humor $(\beta=-0.27, p<0.05)$, self-enhancing humor $(\beta=-0.31, p<0.05)$, aggressive Humor $(\beta=0.17, p<0.05)$, and self-defeating humor $(\beta$ $=0.20, p<0.05)$ are significant predictors of learners' anxiety. However, among four sub-constructs of humor styles, only affiliative humor $(\beta=-0.32, p<0.05)$, and self-enhancing humor $(\beta=-0.25, p<0.05)$ are positive significant predictors of learners' language achievement. In addition, language achievement is predicted negatively by anxiety $(\beta=-0.26, p<0.05)$. Two paths from aggressive humor to language proficiency $(\beta=0.09$, $p>0.05)$, and from self-defeating humor to language proficiency $(\beta=0.07, p>0.05)$ were not significant and removed from the model. Table 4 indicates the results of Pearson correlation among Iranian EFL learners' humor style, anxiety, and language achievement.

As it can be seen in Table 4, among four sub-constructs of humor style, affiliative humor $(r=-0.30, p<$ $0.05)$, and self-enhancing humor $(r=-0.36, p<0.05)$ have negative correlation with anxiety and aggressive humor $(r=0.13, p<0.05)$, and self-defeating humor $(r=0.22, p<0.05)$ have negative correlation with anxiety. In addition, affiliative humor $(r=0.39, p<0.05)$, and self-enhancing humor $(r=0.24, p<0.05)$ have positive correlation with proficiency. However, no significant correlation was found between aggressive humor $(r=$ $0.09, p>0.05)$, and self-defeating humor $(r=0.05, p>0.05)$ and proficiency have negative correlation with anxiety. Besides, there is a weak negative correlation between anxiety and proficiency $(r=-0.33, p<0.05)$. 
Table 4

Results of Correlation Among Iranian EFL Learners' Humor Style, Anxiety, and Language Achievement

\begin{tabular}{|c|c|c|c|c|c|c|}
\hline & 1 & 2 & 3 & 4 & 5 & 6 \\
\hline 1. Affiliative humor & 1.00 & & & & & \\
\hline 2. Self-enhancing humor & $0.88^{* *}$ & 1.00 & & & & \\
\hline 3. Aggressive humor & $-0.46^{* *}$ & $-0.42^{* *}$ & 1.00 & & & \\
\hline 4. Self-defeating humor & $-0.54^{* *}$ & $-0.39^{* *}$ & $0.63^{* *}$ & 1.00 & & \\
\hline 5. Anxiety & $-0.30^{* *}$ & $-0.36^{* *}$ & $0.13^{*}$ & $0.22^{* *}$ & 1.00 & \\
\hline 6. Proficiency & $0.39^{* *}$ & $0.24^{* *}$ & 0.09 & 0.05 & $-0.33^{* *}$ & 1.00 \\
\hline
\end{tabular}

Notes. " Correlation is significant at the level of 0.01 ; " Correlation is significant at the level of 0.05 .

\section{Discussion and Conclusion}

Taken together, the results of the present study did indicate that adaptive Humor styles (affiliative humor and self-enhancing humor) are negative and significant predictors of learners' anxiety and mal-adaptive humor styles (aggressive and self-defeating humor) are positive significant predictors of learners' anxiety. In other words, positive forms of humor decreases learners' level of anxiety and negative forms of humor increases their anxiety. These results are consistent with the claims of Martin et al. (2003). The authors theorized that self-enhancing humor as an adaptive style should be an effective shield against depression or anxiety and be negatively associated to neuroticism. Martin and Lefcourt (1983) discovered a considerable and adaptive impact of humor in moderating the impact of stress. Individuals high in humor seemed to be applying an adaptive coping style instead of only having a lower happening of stress. They accomplish that humor is an adaptive coping instrument that support people cope with stress. Martin et al. (2003) also claimed that in compare to self-enhancing humor, which is an effective coping strategy, self-defeating humor style is assumed to be a struggle avoidant procedure. In other words, this style is expected to be connected to general low-self-esteem and an incapability to confront others. As with violent humor, self-defeating humor is theorized to be associated with neuroticism, depression, anxiety, and other negative emotional conditions. Nevertheless, these outcomes are unpredictable with Jordan's (2002) outcome that establishing humor has no significant effect on stress.

Besides, it was revealed that both affiliative humor and self-enhancing humor styles are positive and significant predictors of learners' proficiency. These results are consistent with previous studies in the field of language learning (Askildson, 2005; Deygan Darweesh Al-Duleimi \& Naji Aziz, 2016; Munoz-Basols, 2005). They strongly confirmed the effectiveness of humor as an aid to learning and teaching.

In addition, language proficiency is predicted negatively by anxiety. Previous studies found the same association between language learning and anxiety (Aida, 1994; Brown, 2000; Cheng, 2002; Ewald, 2007; Horwitz et al., 1986; Saito \& Samimy, 1996; Young, 1992).

The findings of the current study, though preliminary in nature, would seem to strongly support many of the advantageous pedagogical impacts of humor style in the language learning as discussed in the reviewed related literature. With regards to the field of foreign language, humor has been identified as a powerful means to decrease students' anxiety in a foreign language learning situations and it hence helps language learners both in performing in a foreign language and in reducing negative emotions.

Generally, all the above-mentioned benefits combined create humor an effective and influential teaching instrument to be applied in the foreign language classroom. If applied properly and with care, humor can 
support to simplify both teaching and learning procedures and lead to a constructive classroom environment and to the emotional and mental well-being of all participants engaged. Hence, teachers required to set separately time so as to improve strategies and infuse humor in their own teaching practice for the advantage of their students in addition to their own. So as to be able to apply humor successfully, nevertheless, teachers should attention and be conscious of the function that humor plays not only in the target language and as a pedagogical instrument in the foreign language classrooms, but also in the students' personal progress. Since the present study was done in private language institutes, the results cannot be safely generalized to other contexts of English language learning. In addition, only advanced language learners were participated in this study. Thus, future studies may account for these limitations.

\section{References}

Aida, Y. (1994). Examination of Horwitz, Horwitz, and Cope's construct of foreign language anxiety: The case of students of Japanese. Modern Language Journal, 78(2), 155-168.

Askildson, L. (2005). Effect of humor in the language classroom: Humor as a pedagogical tool in theory and practice. Arizona Working Papers in Second Language Acquisition and Teaching, 12, 45-61.

Azizinezhad, M., \& Hashemi, M. (2011). Humour: A pedagogical tool for language learners. Procedia-Social and Behavioral Sciences, 30, 2093-2098.

Banas, J. A., Dunbar, N., Rodriguez, D., \& Liu, S. J. (2011). A review of humor in educational settings: Four decades of research. Community Education, 60(1), 115-144.

Bell, N. (2005). Exploring L2 language play as an aid to SLL: A case study of humour in NS-NNS interaction. Applied Linguistics, 26(2), 192-218.

Brown, H. D. (2000). Principles of language learning and teaching. New York: Addison Wesley Langman.

Cheng, Y. S. (2002). Factors associated with foreign language writing anxiety. Foreign Language Annals, 35(6), 647-656.

Deygan Darweesh Al-Duleimi, A., \& Naji Aziz, R. (2016). Humour as EFL learning-teaching strategy. Journal of Education and Practice, 7(10), 105-115.

Ewald, J. D. (2007). Foreign language learning anxiety in upper-level classes: Involving students as researchers. Foreign Language Annals, 40(1), 122-142.

Gregersen, T. (2003). To err is human: A reminder to teachers of language-anxious students. Foreign Language Annals, 36(1), 25-32.

Horwitz, E. K., Horwitz, M., \& Cope, J. (1986). Foreign language classroom anxiety. The Modern Language Journal, 70(2), 125-132.

Jordan, M. K. (2002). The relationship between stress and humor with Asian college student (MA thesis, University of Nebraska, Omaha). Retrieved from https://pdfs.semanticscholar.org/b6e9/f58479c8eb72bc1ab7e1f707d9f8915181a4.pdf

Ketabi, S., \& Simin, S. (2009). Investigating Persian EFL teachers' and learners' attitudes toward humor in class. International Journal of Language Studies, 3(4), 435-452.

Krashen, S. D. (1985). The input hypothesis: Issues and implications. New York: Longman.

MacIntyre, P. D., \& Gardner, R. C. (1991). Methods and results in the study of anxiety and language learning: A review of the literature. Language Learning, 41(1), 85-117.

MacIntyre, P. D., \& Gardner, R. C. (1994). The subtle effects of language anxiety on cognitive processing in the second language. Language Learning, 44, 283-305.

Martin, R. A., \& Dobbin, J. P. (1988). Sense of humor, hassles, and immunoglobulin A: Evidence for a stress-moderating effect of humor. International Journal of Psychiatry in Medicine, 18(2), 93-105.

Martin, R. A., \& Lefcourt, H. M. (1983). Sense of humor as a moderator of the relation between stressors and moods. Journal of Personality \& Social Psychology, 45(6), 1313-1324.

Martin, R. A., Kuiper, N. A., Olinger, L. J., \& Dance, K. A. (1993). Humor, coping with stress, self-concept, and psychological well-being. Humor: International Journal of Humor Research, 6(1), 89-104.

Martin, R. A., Puhlik-Doris, P., Larsen, G., Gray, J., \& Weir, K. (2003). Individual differences in uses of humor and their relation to psychological well-being: Development of the humor styles questionnaire. Journal of Research in Personality, 37(1), 48-75. 
McClelland, D. C., \& Cheriff, A. D. (1997). The immune enhancing effects of humor on secretory IgA and resistance to respiratory infections. Psychology and Health, 12, 20-344.

Munoz-Basols, J. (2005). Learning through humor: Using humorous resources in the teaching of foreign languages. The A.T.I.S Bulletin. Retrieved from http://todoele.net/materiales/LearningHumor_\%20JavierMunoz.pdf

Saito, Y., \& Samimy, K. K. (1996). Foreign language anxiety and language performance: A study of learner anxiety in beginning, intermediate, and advanced-level college students of Japanese. Foreign Language Annals, 29(2), 239-251.

Teslow, J. L. (1995). Humor me: A call for research. Educational Technology Research and Development, 43(3), 6-28.

Thorson, J. A., \& Powell, F. C. (1993). Development and validation o f a multidimentional sense of humor scale. Journal of Clinical Psychology, 49(1), 13-23.

Thorson, J. A., Powell, F. C., Sarmany-Schuller, I., \& Hampes, W. P. (1997). Psychological health and sense of humor. Journal of Clinical Psychology, 53(6), 605-619.

Young, D. J. (1991). Creating a low-anxiety classroom environment: What does foreign language anxiety research suggest? Modern Language Journal, 75, 426-437.

Young, D. J. (1992). Language anxiety from the foreign language specialists' perspective: Interviews with Karshen, Omaggio, Hadley, Terrell, and Rardin. Foreign Language Annals, 25(2), 157-172.

Ziyaeemehr, A., Kumar, V., \& Abdullah, M. S. F. (2011). Use and non-use of humor in academic ESL classrooms. English Language Teaching, 4(3), 111-119. 